\title{
Рекомендації щодо оцінювання бойової ефективності застосування військ із урахуванням створення та застосування різних варіантів розвідувально-ударних систем в операціях
}

\author{
Артем Ремез ${ }^{1 \mathrm{~A}}$ \\ А Національний університет оборони України імені Івана Черняховського, пр-кт Повітрофлотський, 28, г. Київ, 03049, Україна
}

Received: June 7, 2021 | Revised: June 20, 2021 | Accepted: June 30, 2021

DOI: $10.33445 /$ sds.2021.11.3.18

\begin{abstract}
Анотація
Досвід застосування військ в операціях об'єднаних сил показав необхідність удосконалення існуючих підходів щодо принципів та способів бойового застосування угруповань військ. Сьогодні чітко просліджується тенденція переходу від платформоцентричних до мережоцентричних принципів ведення бойових дій. Одним із можливих шляхів переходу до мережоцентричних принципів ведення бойових дій $\epsilon$ створення розвідувально-ударних систем шляхом ситуаційного інтегрування наявних сил і засобів розвідки, управління та ураження у цільові системи в єдиному інформаційному просторі. Розвідувально-ударна система повинна бути побудована із множини підсистем об'єднаних інформаційними відносинами, які функціонують, як одне ціле, на основі єдиних принципів і правил, $з$ погодженими основними вимогами до їх складових. Інтегрування різних сил і засобів у цільові системи створює передумови щодо наявності декілька можливих варіантів цих систем, які мають різні оцінки ефективності їх застосування, вартісні показники їх створення, утримання та застосування, а також різні часові інтервали щодо їх створення та приведення у бойову готовність. Одним із критерієм прийняття рішення щодо доцільності вибору того чи іншого варіанту розвідувально-ударної системи $€$ показник приросту ефективності бойового застосування військ за рахунок принципів синергетичного ефекту під час застосування розвідувально-ударних систем. Тому практична реалізація пропозицій щодо створення нових або удосконалення існуючих розвідувально-ударних систем у Збройних Силах України, а також розроблення методичних підходів щодо вибору найбільш раціонального варіанту цих систем буде вимагати наявності певних методичних рекомендацій щодо роз'яснення підходів до оцінювання бойової ефективності застосування військ із урахуванням результатів застосування того чи іншого варіанту розвідувально-ударної системи в операціях Об'єднаних Сил Збройних Сил України. Автором в статті запропоновано алгоритм оцінювання бойової ефективності застосування військ з урахуванням створення та застосування різних варіантів розвідувальноударних систем в операції, на основі якого сформовано основні рекомендації щодо оцінювання бойової ефективності з урахуванням застосування розвідувально-ударних систем в операції, наведено практичні розрахунки бойової ефективності різних варіантів розвідувально-ударних систем, а також запропоновано номограму вибору раціональної кількості засобів ураження розвідувально-ударної системи за умов заданої кількості засобів ураження противника.
\end{abstract}

Ключові слова: оцінювання, розвідувально-ударна система, синергетичний ефект, війська.

\section{Постановка проблеми}

Сьогодні забезпечення воєнної безпеки держави $€$ комплексом пріоритетних заходів щодо ефективного розвитку оборонних структур, які залучаються до виконання завдань оборони держави [1-6]. Сучасні вимоги до якості зразків озброєння та

\footnotetext{
1 *Corresponding author: ад’юнкт, e-mail: remez.art.86@gmail.com, ORCID: 0000-0003-4970-1097
} 
військової техніки (ОВТ) постійно зростають, що в свою чергу формує потреби оновлення та удосконалення ОВТ, яке знаходиться на озброєнні ЗС України та інших військових формувань залучених до виконання завдань оборони держави. У контексті цих питань одним із важливих завдань подальшого розвитку ОВТ ЗС України $\epsilon$ створення нових та удосконалення існуючих масштабних розвідувально-ударних систем шляхом інтеграції ключових засобів розвідки, управління та ураження в єдині комплекси та системи 3 метою підвищення ефективності бойового застосування військ (сил). Отже, планований перехід від платформоцентричних до мережоцентричних принципів бойового застосування угруповань військ повинен супроводжуватися розробкою та впровадженням технологій оптимальної (раціональної) організації інформаційного забезпечення управління діями частин та підрозділів ЗС України.

Досвід застосування військ в операціях Об'єднаних сил (ООС) на Сході країни показав $[1,4]$, що сьогодні $€$ необхідним удосконалення існуючих підходів щодо принципів та способів бойового застосування угруповань військ. Одним із можливих шляхів переходу до мережоцентричних принципів ведення бойових дій $\epsilon$ створення розвідувально-ударних систем шляхом ситуаційного інтегрування наявних сил і засобів розвідки, управління та ураження у цільові системи в єдиному інформаційному просторі.

\section{Аналіз останніх досліджень та публікацій}

Аналіз останніх досліджень та публікацій показав [1-12], що розвідувально-ударна система (РУС) повинна бути побудована із множини підсистем об'єднаних інформаційними відносинами, які функціонують, як одне ціле, на основі єдиних принципів і правил, з погодженими основними вимогами до їх складових. Інтегрування різних сил і засобів у цільові системи створює передумови щодо наявності декілька можливих варіантів цих систем, які мають різні оцінки ефективності їх застосування $[3,5,10]$ вартісні показники їх створення, утримання та застосування [5], [10] а також різні часові інтервали щодо їх створення та приведення у бойову готовність $[3,9]$.

Сьогодні одним із критерієм прийнятяя рішення щодо доцільності вибору того чи іншого варіанту РУС $\epsilon$ показник приросту ефективності бойового застосування військ за рахунок принципів синергетичного ефекту під час застосування РУС в операції $[6,10,12]$. Тому практична реалізація пропозицій щодо створення нових або удосконалення існуючих розвідувально-ударних систем у ЗС України, а також розроблення методичних підходів щодо вибору найбільш раціонального варіанту цих систем буде вимагати наявності певних методичних рекомендацій щодо роз'яснення підходів до оцінювання бойової ефективності застосування військ із урахуванням результатів застосування того чи іншого варіанту розвідувально-ударної системи в операціях Об'єднаних Сил Збройних Сил України.

\section{Постановка завдання}

Метою статті $\epsilon$ формування дієвих методичних рекомендацій щодо оцінювання бойової ефективності застосування військ із урахуванням створення (удосконалення) різних варіантів розвідувально-ударних систем для підвищення обґрунтованості управлінських рішень щодо вибору раціонального варіанту РУС за критерієм "ефективність - вартість".

\section{Виклад основного матеріалу}

Перед керівництвом держави та 3 C України, в умовах необхідності оновлення озброєння ЗС України та недостатнього їх фінансування постійно постає завдання обґрунтування вибору зразків озброєння на перспективу [1-5]. Обрані в програмах 
розвитку ОВТ та ЗС України перспективні зразки озброєння повинні задовольняти вимоги щодо вирішення завдань, які постають перед 3С, і бути економічно досяжними (реальними). Сьогодні у багатьох країнах світу здійснюється перегляд теорії побудови і практики застосування, як нових комплексів, так і існуючих зразків озброєння з урахуванням організації та ведення бойових дій у єдиному інформаційному та кібернетичному просторі [1-12]. А також в сучасних умовах ведення бойових дій активно досліджується питання, як досягти скорочення часу повного циклу бойового застосування зразка або комплексу озброєння для випередження противника у досягненні мети [4].

Сьогодні в умовах обмеженого фінансового ресурсу та обмежень щодо здатності обороно промислового комплексу (ОПК) України до повного циклу розроблення складних зразків озброєння та військової техніки (кораблі, літаки тощо) $[4,8]$, а також не виключенням $\epsilon$ розроблення нових варіантів РУС доцільно проведення наступних основних робіт: аналіз загроз та визначення основних завдань $3 \mathrm{C}$ України у сфері ймовірного збройного протистояння, а також формування багаторівневого переліку критично важливих об'єктів противника, які плануються до ураження; визначення раціонального складу сил і засобів РУС для різних варіантів збройних зіткнень, які здатні адекватно виконати завдання щодо протидії противнику на відповідних операційних напрямках i оперативно впливати на об'єкти противника; розроблення та вдосконалення форм і способів ведення бойових дій у складі об'єднаних сил (OC); удосконалення технологій вогневого (функціонального, радіоелектронного) ураження і забезпечення бойових дій; оптимізації складу сил і засобів елементів РУС, а також реструктуризація заходів бойової підготовки.

у $[9,11]$ наведено основні положення методичного підходу щодо воєнноекономічного обґрунтування вибору раціонального варіанту РУС для ЗС України, який на відміну від існуючих під час вибору пріоритетного варіанту РУС дозволяє урахувати показники бойової ефективності застосування варіантів РУС в операції, достатність економічних можливостей держави щодо створення, утримання та застосування визначеного варіанту РУС, своєчасність створення та приведення обраного варіанту РУС у бойову готовність 3 урахуванням особливостей невизначеності обстановки під час прийнятя рішень.

Розроблення такого методичного підходу та пошук шляхів його практичної реалізації в штабах, службах ЗС України під час прийняття рішень щодо вибору раціонального варіанту РУС за різних умов обстановки проведення операцій Об'єднаних Сил (ООС) формує необхідність розроблення ряду дієвих рекомендацій щодо порядку та змісту оцінювання бойової ефективності застосування військ із урахуванням створення та застосування різних варіантів РУС.

Головною метою розроблених рекомендацій $\epsilon$ формування загальної послідовності проведення розрахунків бойової ефективності застосування військ із урахуванням одночасного застосування різних варіантів РУС з метою прийнятяя рішення щодо вибору найбільш ефективного за тих чи інших умов обстановки.

Загальний алгоритм оцінювання бойової ефективності застосування військ 3 урахуванням створення та застосування РУС в операції наведено на мал. 1. Наведений у [9, 11] методичний підхід обґрунтування вибору раціонального варіанту РУС та запропонований алгоритм оцінювання бойової ефективності застосування військ з урахуванням вибору раціонального варіанту РУС в операції (мал.1) дозволяє вирішити як пряму, так і обернену постановку задачі (оцінка бойової ефективності фіксованого складу (РУС) або вибір необхідного складу РУС за умов заданих сил противника та оцінки ефективності виконання бойового завдання (БЗ)). 


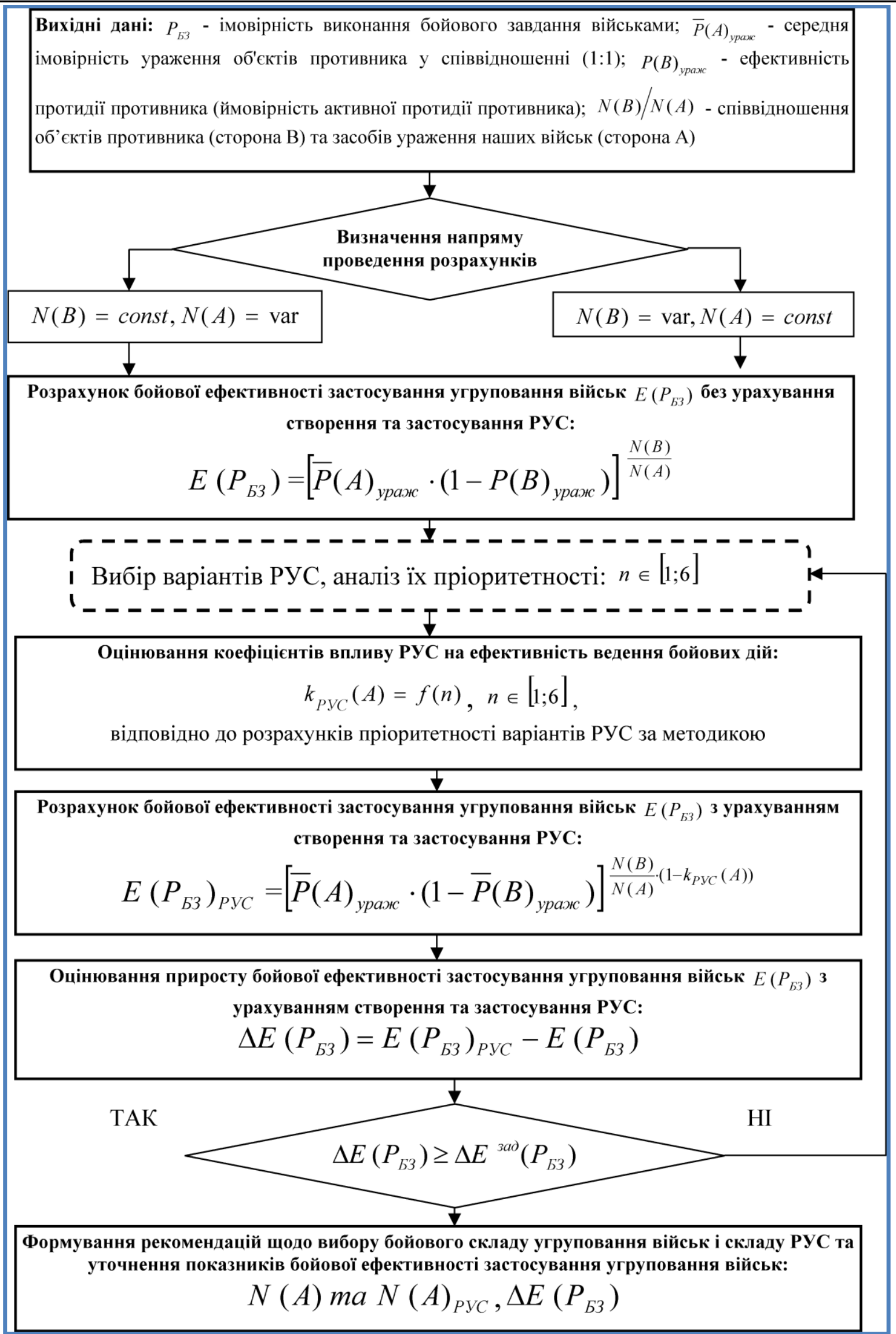

Малюнок 1 - Алгоритм оцінювання бойової ефективності застосування військ з урахуванням створення та застосування РУС в операції 
Основними вхідними даним для проведення розрахунків бойової ефективності застосування військ із урахуванням створення та застосування РУС в операції $€: P_{\text {Бз }}$ імовірність виконання бойового завдання військами; $\bar{P}(A)_{\text {ураж }}$ - середня імовірність ураження об'єктів противника у співвідношенні $(1: 1) ; \quad P(B)_{\text {ураж }}$ - ефективність протидії противника (імовірність активної протидії противника); $N(B) / N(A)$ - співвідношення об'єктів противника (сторона В) та засобів ураження наших військ (сторона A).

Співвідношення сил - це відношення (або різниця) бойових можливостей або бойових потенціалів засобів противника та наших військ. Для проведення розрахунків у якості співвідношення обрано показник співвідношення об'єктів противника та засобів ураження наших військ. Бойові можливості засобів нападу визначаються кількістю уражених із заданою ймовірністю об'єктів. За відсутності протидії - це сумарні бойові можливості усіх засобів ураження, які характеризуються загальною кількістю полігонних нарядів для ураження об'єктів різних груп, оскільки ймовірність доставки відповідного полігонного наряду до об'єкта практично дорівнює одиниці (якщо не враховувати експлуатаційну надійність засобів доставки). За наявності ефективної протидії засобам ураження противника шляхом застосування РУС противник буде нести втрати, які знижують його бойові можливості стосовно ураження наших об'єктів.

Застосування РУС повинно знищити або відвернути таку кількість засобів повітряного нападу у районах базування або маршрутах слідування, за якої співвідношення сил противника та наших військ стає не менше потрібного. Визначення такого співвідношення набуває великого значення для обґрунтування величини виділення сил та засобів для проведення операції (бою), організації взаємодії видів збройних сил, особливо при плануванні стратегічної операції.

Таким чином розрахунок ефективності бойового застосування угруповання наших військ $E\left(P_{\text {Бз }}\right)$ без урахування створення та застосування РУС може бути здійснено за формулою (мал. 1):

$$
E\left(P_{\text {Б3 }}\right)=\left[\overline{\mathrm{P}}(\mathrm{A})_{\text {ураж }} \cdot\left(1-\mathrm{P}(\mathrm{B})_{\text {ураж}}\right)\right]^{\frac{N(B)}{N(A)}} .
$$

У разі створення та застосування різних $i$-х варіантів РУС вираз (1) буде мати вигляд:

$$
E\left(P_{\mathrm{Б} 3}\right)=\left[\overline{\mathrm{P}}(\mathrm{A})_{\text {ураж}} \cdot\left(1-\mathrm{P}(\mathrm{B})_{\text {ураж}}\right)\right]^{\frac{N(B)}{N(A)} \cdot\left(1-k_{i} \mathrm{PyC}(\mathrm{A})\right)},
$$

де $k_{\text {i рус }}(\mathrm{A}), k_{\text {i рус }}(\mathrm{A}) \in[0 ; 1]-$ коефіцієнт впливу застосування $i$-го варіанту РУС на ефективність ведення бойових дій в операції.

У табл. 2 наведено приклад проведення практичних розрахунків щодо оцінювання бойової ефективності застосування двох різних варіантів РУС в операції. На мал. 2 показано загальний вид результатів оцінювання бойової ефективності застосування військ в ООС 3 урахуванням та без урахування створення та застосування запропонованих у [11] шести різних варіантів РУС за умови, що кількість засобів ураження наших військ фіксована $N(A)=$ const, а кількість засобів ураження військ противника змінна $N(B)=v a r$.

Отримані результати показують що практично усі варіанти застосування РУС дають приріст бойової ефективності, але цей приріст необхідно під час вибору раціонального варіанту РУС співставляти із вартісними показниками створення та застосування варіантів РУС, а також часовими інтервалами щодо створення та приведення варіантів РУС у бойову готовність. 
Таблиця 2 - Результати практичних розрахунків щодо оцінювання бойової ефективності застосування двох різних варіантів РУС в операції

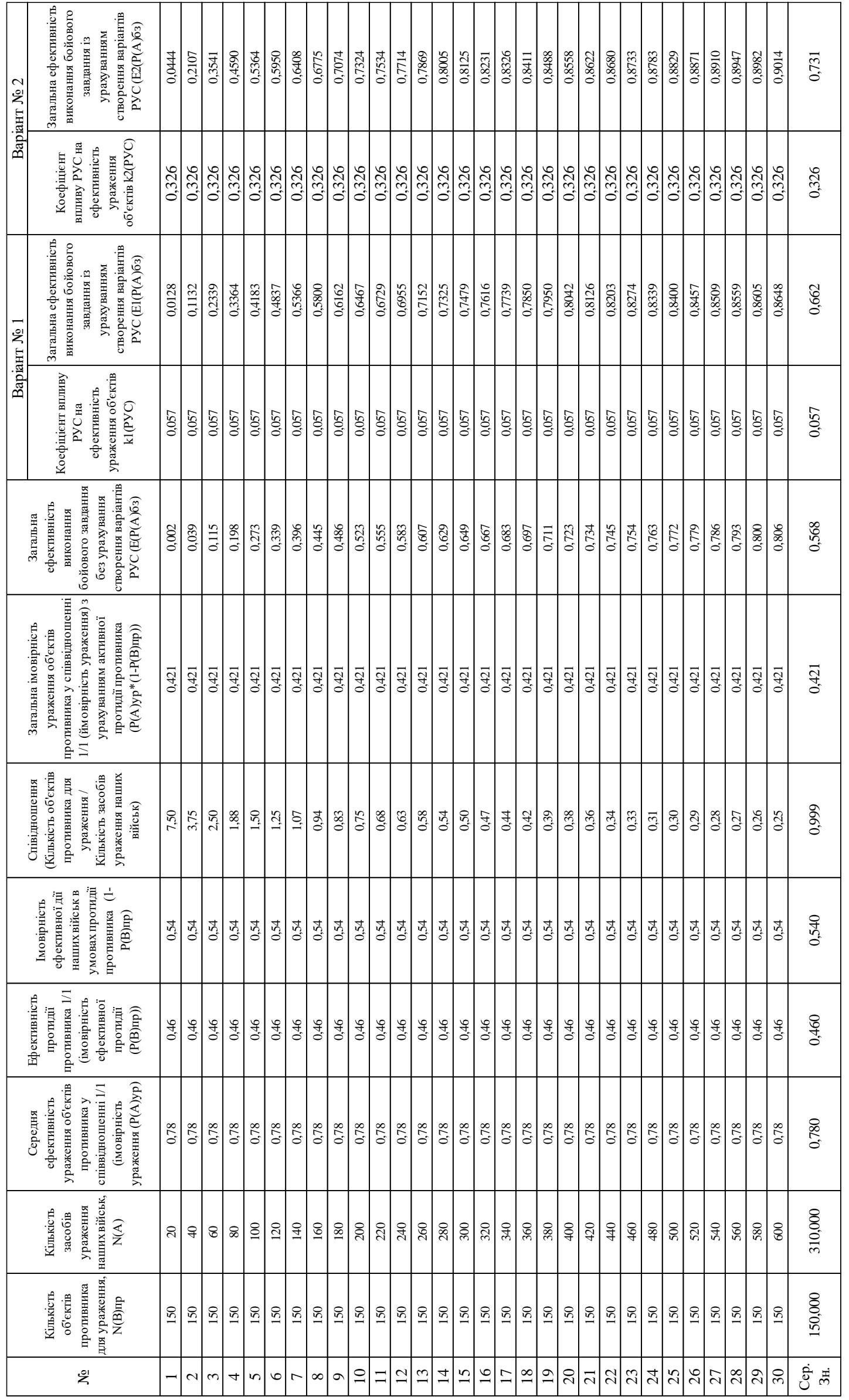




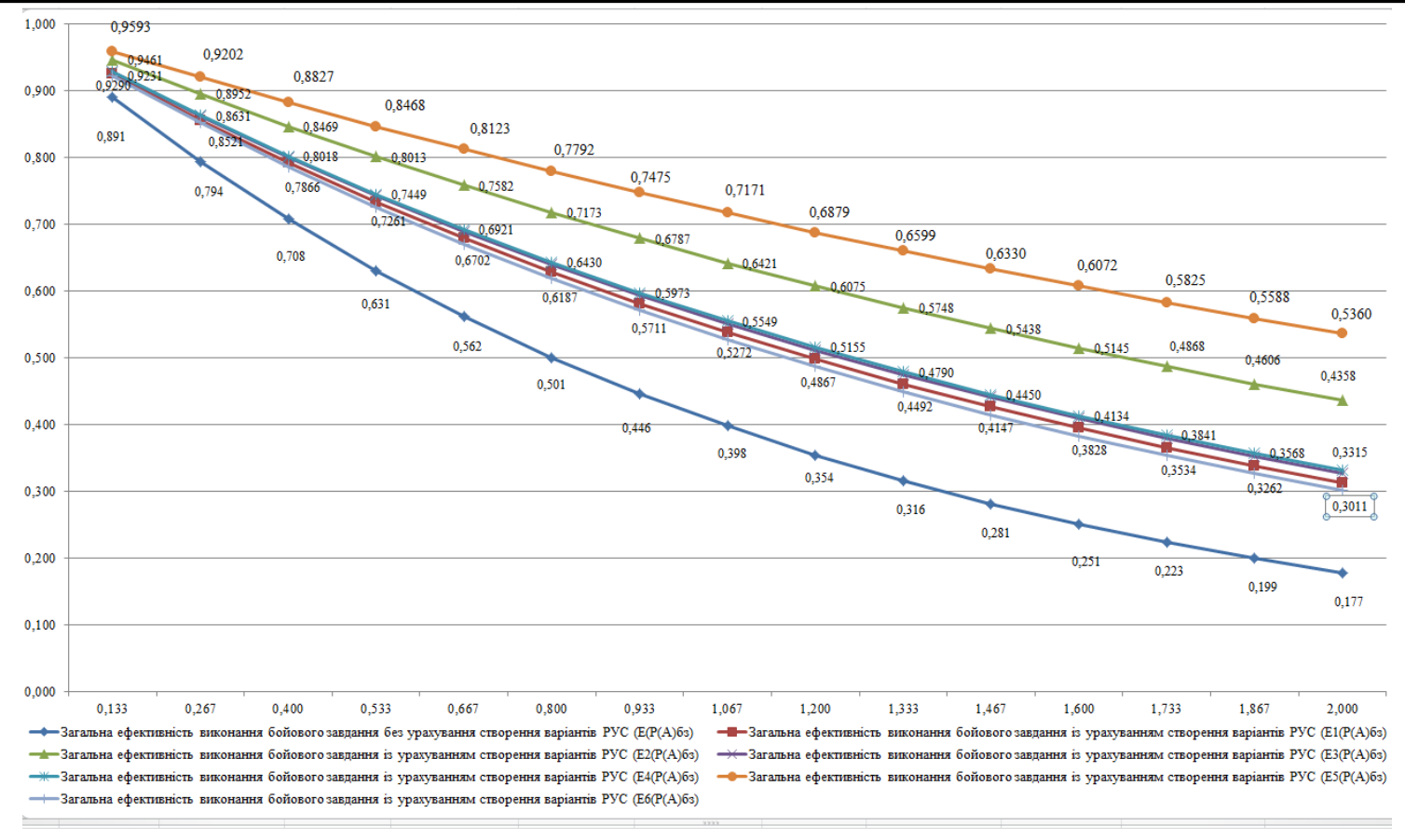

Малюнок 2 - Результати оцінювання бойової ефективності застосування військ в ООС 3 урахуванням та без створення та застосування шести різних варіантів РУС

Результати розрахунків загальної середньої ефективності (приросту) виконання бойових завдань із урахуванням створення та застосування варіантів різних РУС (E(P(A)бз) за

умов зміни співвідношення складу наших військ до фіксованого складу військ противника $(\mathrm{N}(\mathrm{A})=$ var, $\mathrm{N}(\mathrm{B})=$ const $)$ наведено на мал. 3.

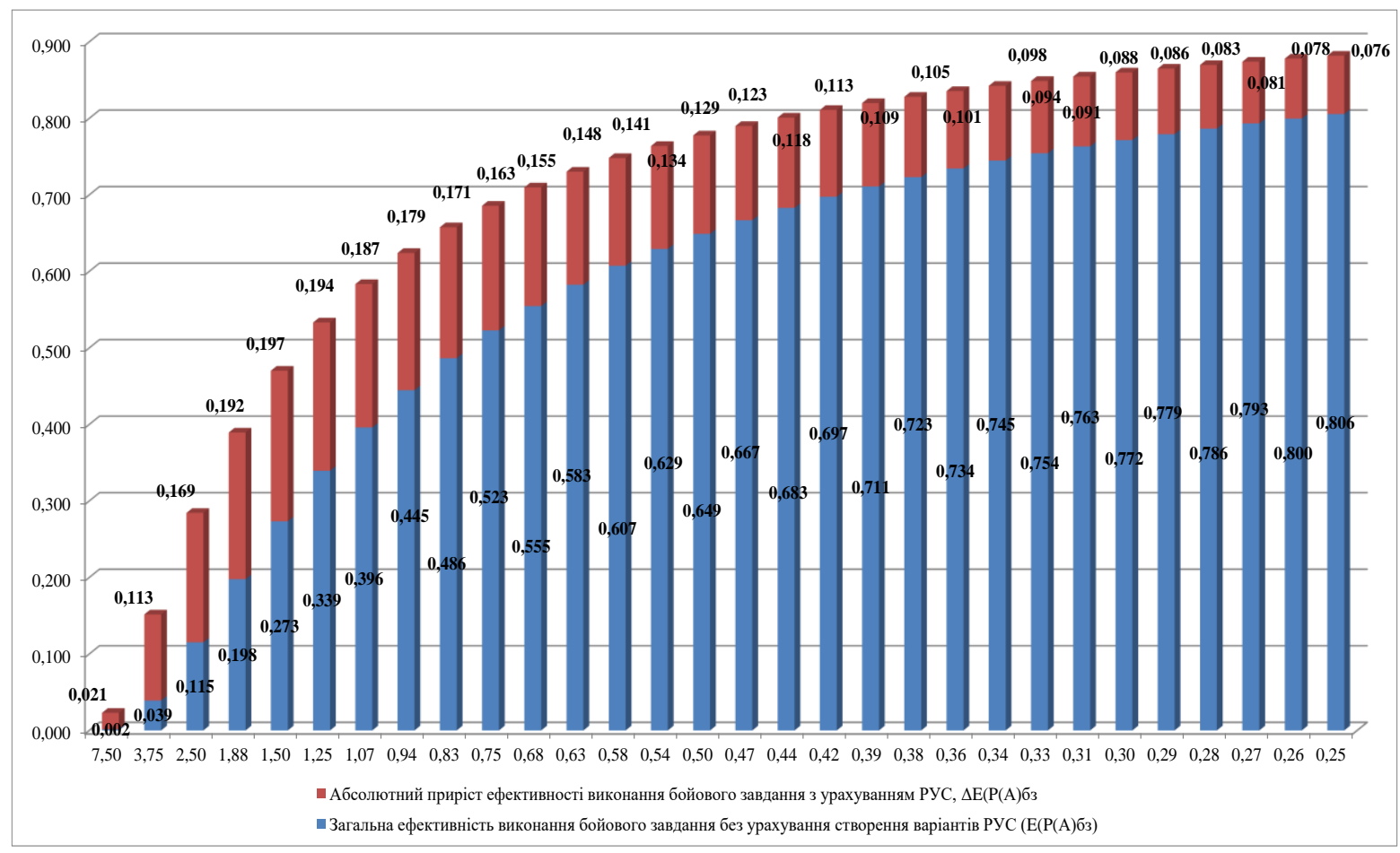

Малюнок 3 - Результати оцінювання загальної середньої ефективності (приросту) виконання бойових завдань із урахуванням створення та застосування варіантів різних РУС 
Таким чином до основних рекомендацій щодо оцінювання бойової ефективності застосування військ в операції з урахуванням створення та застосування різних варіантів РУС можна віднести наступне:

головним критерієм бойової ефективності $\epsilon$ імовірність виконання бойового завдання угрупованням військ в операції;

розрахунок бойової ефективності здійснюється за різних умов постановки задачі щодо співвідношення сил, тобто, кількість засобів ураження наших військ фіксована, у противника - змінна або кількість засобів противника фіксована, у наших змінна - цей тип задачі дозволяє обрати раціональну кількість засобів ураження для РУС за умов заданого противника;

під час розрахунків необхідно враховувати показник ефективності дій противника імовірність ефективної протидії РУС;

розраховані показники бойової ефективності застосування військ із урахуванням створення та застосування різних варіантів РУС повинні бути співставленні із вартісними показниками створення РУС та часовими показниками приведення їх у бойову готовність 3 метою вибору найбільш пріоритетного варіанту за різних умов обстановки тощо.

Основними припущеннями під час проведення розрахунків повинні бути те, що:

різні за своїми характеристиками бойові одиниці засобів ураження противника і наших військ замінюються еквівалентними (визначеними з урахуванням їх важливості під час ведення бойових дій);

кожна бойова одиниця сторони, що обороняється, в одному ударі (нальоті) знищує не більше однієї бойової одиниці сторони, яка нападає, із заданою ймовірністю;

уразливість усіх об'єктів приймається середнім значенням для визначеного класу засобів ураження; усі бойові одиниці беруть участь в операції (бойових діях) тощо.

3 урахуванням прийнятих припущень визначимо основні фактори, які впливають на наслідки протистояння (ведення бойових дій) противника та наших військ, а саме:

кількість засобів ураження противника та наших військ, що беруть участь в бойових діях;

величини полігонних нарядів, необхідних для ураження із заданою ймовірністю об'єктів різних груп;

кількість засобів протидії засобам ураження кожної сторони;

значення ймовірностей ураження окремого засобу нападу засобом оборони;

кількість об'єктів, які можуть стати об'єктами удару для засобів нападу тощо.

Урахування тільки вказаних факторів й складає сутність спрощеної моделі.

Потрібні сили наших військ за заданих сил противника можуть бути визначені за формулою:

$$
N_{0}(\mathrm{~A})=N(B) \cdot \frac{\ln \left(\frac{Q_{\text {ураж} \cdot \eta \cdot Q}}{N \cdot 100}\right)}{\ln \left(1-P_{\mathrm{cp}}\right)},
$$

де $N_{0}(A)$ - потрібні сили наших військ у разі оборони своїх позицій, які включають кількість бойових одиниць, що мають можливість уразити бойові одиниці засобів нападу зі середньою ймовірністю $P_{c p}$;

$N(B)$ - сили противника, у разі якщо противник здійснює напад, виражені кількістю бойових одиниць, які мають здатність уражати об'єкти наших військ;

$\eta$ - полігонний наряд засобів повітряного нападу, виражений кількістю бойових одиниць (літаків, ракет, стволів артилерії тощо), достатніх для ураження об'єктів противника певного типу;

$Q$ - загальна кількість об'єктів, які можуть бути об'єктами удару для засобів нападу противника;

$Q_{y p}$ - припустимий рівень збитку у вигляді уражених об'єктів наших військ, виражених у відсотках від загальної кількості об'єктів $Q$, де припустимою кількістю об'єктів вважається така кількість, за якої ще гарантується виконання поставленої задачі сторони, яка обороняється.

Запропонований на мал. 1 підхід щодо оцінювання бойової ефективності застосування військ 3 урахуванням створення та застосування РУС в операції можна застосовувати для підвищення оперативності проведення розрахунків та представити його графоаналітичним методом у вигляді 
номограми (мал. 3), яка дозволяє за умов обмеженого часу для проведення розрахунків вирішити задачу оцінювання бойової ефективності застосування військ в операції 3 урахуванням застосування різних варіантів РУС за різних умов постановки задачі щодо визначення співвідношення сил, тобто:

пряма задача - кількість засобів ураження наших військ фіксована, у противника змінна;

обернена задача - кількість засобів противника фіксована, у наших змінна.
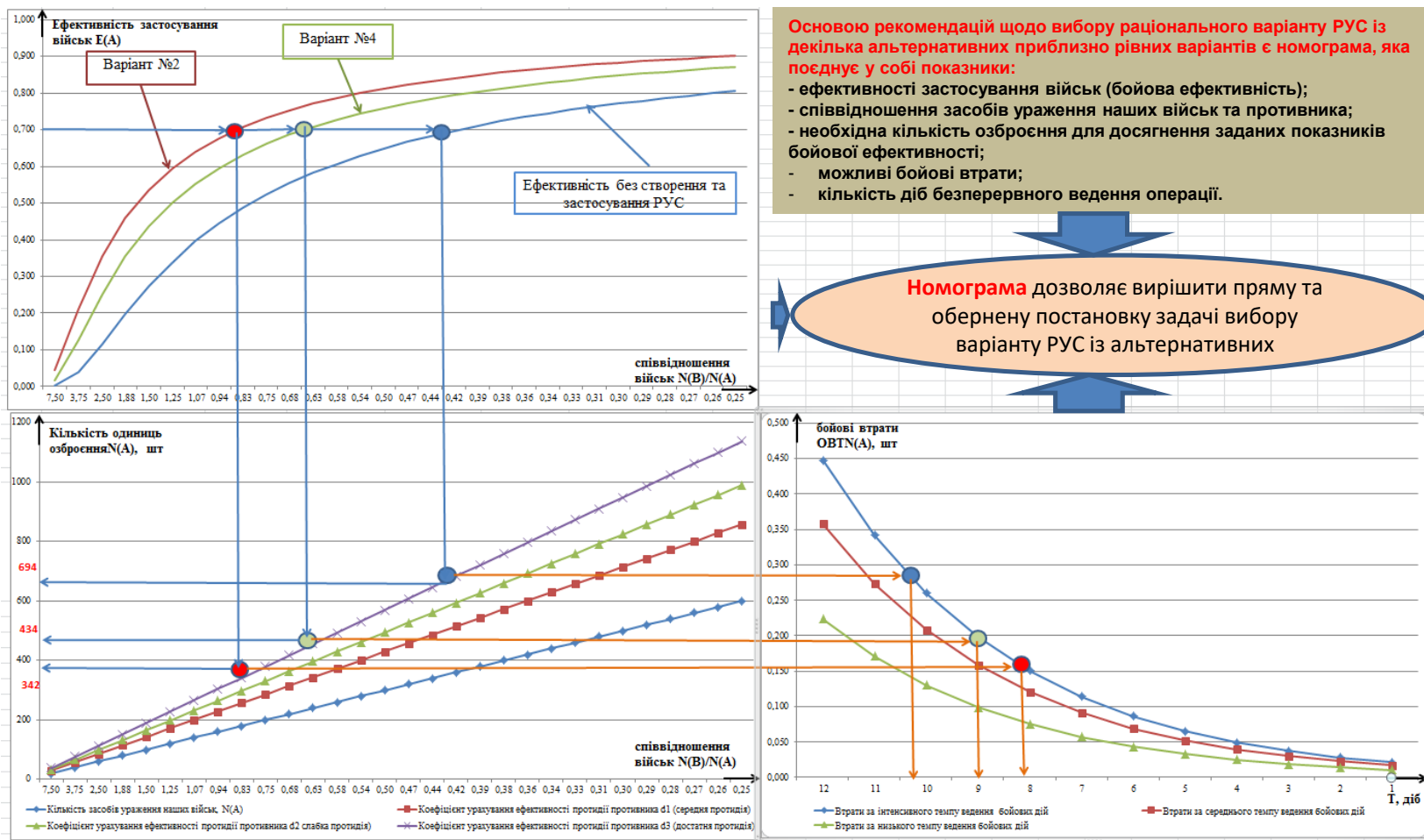

Малюнок 3 - Номограма рішення задач вибору раціонального співвідношення засобів ураження противника та наших військ за показниками приросту бойової ефективності застосування військ

в операції та бойових втрат із урахуванням створення та застосування різних варіантів РУС

Вирішення оберненої задачі дозволяє обрати раціональну кількість засобів ураження для РУС за умов заданого противника, що, в свою чергу, дозволить сформувати рекомендації щодо вибору раціонального

\section{Висновки}

Таким чином, запропоновані у статті рекомендації щодо оцінювання бойової ефективності застосування військ із урахуванням створення та застосування різних варіантів розвідувально-ударних систем в операції дозволять:

підвищити обґрунтованість рішень щодо створення та застосування розвідувальноударних систем ЗС України в операціях;

підвищити оперативність проведення розрахунків щодо оцінювання бойової ефективності застосування військ із бойового складу угруповання військ із урахуванням складу РУС та уточнених показників бойової ефективності застосування угруповання військ під час проведення різного виду операцій.

урахуванням створення та застосування різних можливих варіантів РУС в операції шляхом застосування розробленої номограми;

оцінити доцільність створення різних варіантів РУС на етапі їх проектування, що, в свою чергу, підвищить достовірність результатів оцінювання ефективності їх застосування та обґрунтованість необхідних матеріальних та фінансових ресурсів для створення, утримання та застосування цих варіантів РУС. 
Подальшим напрямом досліджень за тематикою статті $\epsilon$ проведення реальних практичних розрахунків показників бойової ефективності застосування військ в ООС за умов створення декілька варіантів РУС, а також розроблення рекомендацій щодо порядку (послідовності) застосування методики воєнно-економічного обґрунтування варіантів РУС в штабах, службах ЗС України на різних рівнях управління ними.

\section{Список використаних джерел}

1. Світова гібрідна війна: український фронт: монографія / за заг. ред. В.П. Горбуліна. К.: НІСД, 2017. 496 с.

2. Розвідувально-ударні, розвідувальновогневі комплекси (принципи побудови в умовах реалізації концепції мережецентричних війн, оцінка ефективності бойового застосування) : монографія / за заг. ред. В. М. Телелима / В. М. Тарасов, Р. І. Тимошенко, О. М. Загорка. К.: НУОУ ім. Івана Черняховського, 2015. 184 c.

3. Загорка О. М. До питання застосування розвідувально-ударних і розвідувальновогневих комплексів у мережецентричній війні / О. М. Загорка, В. О. Колесников, В. В. Коваль, І. О. Загорка // Наука і техніка Повітряних Сил Збройних Сил України. 2012. № $3 . \quad$ C. $8-13$ URL: http://nbuv.gov.ua/UJRN/Nitps_2012_3_5.

4. Хомчак Р.Б., Семненко О.М., Бокій В.Г., Зварич А.О., Ремез А.В. Теоретичні аспекти прогнозування результатів розвитку Збройних Сил України з урахуванням оцінок достатності економічних можливостей держави // 36. наук. пр. ЦНДІ ЗС України. Київ. 2020. № 2 (93). С. 6-24.

5. Разведывательно-ударные комплексы и разведывательные системы иностранных армий URL: http://studbooks.net/1194609/ bzhd/razvedyvatelno_udarnye_kompleksy_ra zvedyvatelnye_sistemy_inostranny h_armiy.

6. Боевое применение ракетных войск и артиллерии в операциях: учеб. - М.: ВА ГШ ВС РФ, 2006. 304 c.

7. Космос и характер современных военных действий. URL: http://kiksssr.ru/Main_Oko.htm.
8. Semenenko O., Vodchyts O., Bulhakov A., Remez A., Remez V. Methodological approach to justification of decisions on update of samples of weapons and military equipment on the basis of the criteria of economy of economy of performance by them of tasks on purpose // Sciences of Europe, (Praha, Czech Republic), vol 3, № 63 (2021), pp. 49-55

9. Semenenko O., Remez , A., Musienko , V., Motrunych, I., Bulhakov, A., \& Tarasov, O. (2021). Recommendations for application of the methodological approach to the militaryeconomic justification of the choice of a rational variant of the reconnaissance-strike system or complex in the programs (plans). Journal of Scientific Papers "Social Development and Security», 11(2), 209-221. DOI: $10.33445 /$ sds.2021.11.2.18

10. Саяпин О.В., Тиханычев О.В., Чернов Н.А. Создание межвидовой разведывательнопоражающей системы как основы повышения эффективности огневого поражения // Военная мысль, 2017. №6. С. 32-37.

11. Семененко О. М., Ремез А. В., Романченко О. А., Бондаренко О.Є. Загальна структурнологічна схема та зміст методики воєнноекономічного обґрунтування вибору раціонального варіанту розвідувальноударної системи для Збройних Сил України / 36. наук. пр. Центрального науководослідного інституту Збройних Сил України. Київ: ЦНДІ ЗС України, 2020. №4 (95). С. 3645.

12. The Implementation of Network-Centric Warfare. URL: http://www.iwar.org.uk/rma /resources/ncw/implementation-of-NCW.pdf. 
Рекомендации по оценке боевой эффективности применения войск с учётом создания и применения различных вариантов разведывательно-ударных систем в операциях

\author{
Артем Ремез * 1 А \\ * Corresponding author: ${ }^{1}$ адъюнкт, e-mail: remez.art.86@gmail.com, ORCID: 0000-0003-4970-1097 \\ А Национальный университет обороны Украины имени Ивана Черняховского, пр-кт Воздухофлотский, 28, г. Киев, 03049, Украина
}

\begin{abstract}
Аннотация
Опыт применения войск в операциях объединённых сил показал необходимость совершенствования существующих подходов относительно принципов и способов боевого применения группировок войск. Сегодня четко прослеживается тенденция перехода от платформоцентрических к сетецентрическим принципам ведения боевых действий. Одним из возможных путей перехода к сетецентрическим принципам ведения боевых действий является создание разведывательно-ударных систем путем ситуационного интегрирования имеющихся сил и средств разведки, управления и поражения в целевые системы в едином информационном пространстве. Разведывательно-ударная система должна быть построена из множества подсистем, объединенных информационными отношениями, которые функционируют, как одно целое, на основе единых принципов и правил, с согласованными основными требованиями к их составляющих. Интегрирование различных сил и средств в целевые системы создает предпосылки о наличии несколько возможных вариантов этих систем, имеющих различные оценки эффективности их применения, стоимостные показатели их создания, содержания и применения, а также различные временные интервалы по их созданию и приведение в боевую готовность. Одним из критериев принятия решения о целесообразности выбора того или иного варианта разведывательно-ударной системы является показатель прироста эффективности боевого применения войск за счет принципов синергетического эффекта в случае создания и применении разных вариантов разведывательно-ударных систем. Практическая реализация предложений по созданию новых или усовершенствование существующих разведывательно-ударных систем в Вооруженных Силах Украины, а также разработка методических подходов по выбору наиболее рационального варианта этих систем будут требовать наличия определенных методических рекомендаций для разъяснения подходов к оценке боевой эффективности применения войск с учетом результатов применения того или иного варианта разведывательно-ударной системы в операциях Объединенных Сил Вооруженных Сил Украины. Автором в статье предложен алгоритм оценки боевой эффективности применения войск с учетом создания и применения различных вариантов разведывательно-ударных систем в операции, на основе которого сформированы основные рекомендации по оценке боевой эффективности на основе применения разведывательно-ударных систем в операции, а также приведены практические расчеты боевой эффективности различных вариантов разведывательно-ударных систем и предложено номограмму выбора рационального количества средств поражения разведывательно-ударной системы в условиях заданного количества средств поражения противника.
\end{abstract}

Ключевые слова: оценивание, разведывательно-ударная система, синергетический эффект, войска.

\title{
Recommendations for evaluating the battle efficiency of the use of troops taking into account the creation and use of different options of reconnaissance-strike systems in operations
}




\author{
Artem Remez * 1 A \\ * Corresponding author: ${ }^{1}$ PhD student, e-mail: remez.art.86@gmail.com, ORCID: 0000-0003-4970-1097 \\ A National Defence University of Ukraine named Ivan Chernyakhovsky, 28, Povitroflotsky Ave., Kyiv, 03049, Ukraine
}

\begin{abstract}
The experience of using troops in joint force operations has shown the need to improve existing approaches to the principles and methods of combat employment of groupings of troops. Today, there is a clear tendency of transition from platform-centric to network-centric principles of warfare. One of the possible ways of transition to network-centric principles of warfare is the creation of reconnaissance-strike systems by situational integration of existing forces and means of reconnaissance, control and destruction into target systems in a single information space. The reconnaissance-strike systems will be built from a multitude of subsystems united by information relations, which function as a whole, on the basis of common principles and rules, with agreed basic requirements for their components. The integration of various forces and assets into target systems creates the prerequisites for the presence of several possible options for these systems, which have different assessments of the effectiveness of their use, the cost indicators of their creation, maintenance and use, as well as different time intervals for their creation and putting them on alert. One of the criteria for making a decision on the advisability of choosing one or another variant of a reconnaissance-strike systems is an indicator of an increase in the effectiveness of the combat employment of troops due to the principles of synergetic effect in the case of the creation and use of different versions of reconnaissancestrike systems. The practical implementation of proposals for the creation of new or improvement of existing reconnaissance-strike systems in the Armed Forces of Ukraine, as well as the development of methodological approaches for choosing the most rational version of these systems will require certain methodological recommendations to clarify approaches to assessing the combat effectiveness of the use of troops, taking into account the results of applying this or another version of the reconnaissance-strike systems in the operations of the Joint Forces of the Armed Forces of Ukraine. The author in the article proposes an algorithm for assessing the combat effectiveness of the use of troops, taking into account the creation and use of various options for reconnaissance-strike systems in an operation, on the basis of which the main recommendations for assessing combat effectiveness based on the use of reconnaissance-strike systems in an operation are formulated, and practical calculations of the effectiveness of various variants of reconnaissance-strike systems and a nomogram of the choice of a rational number of means of destruction of a reconnaissance-strike systems in conditions of a given number of means of destruction of the enemy is proposed.
\end{abstract}

Keywords: evaluation, reconnaissance and strike system, synergetic effect, troops.

\title{
References
}

1. Svitova hibridna viyna: ukrayins'kyy front: monohrafiya / za zah. red. V.P. Horbulina. K.: NISD, 2017. 496 p.

2. Rozviduval'no-udarni, rozviduval'no-vohnevi kompleksy (pryntsypy pobudovy $v$ umovakh realizatsiyi kontseptsiyi merezhetsentrychnykh viyn, otsinka efektynnosti boyovoho zastosuvannya): monohrafiya / za zah. red. V. M. Telelyma / V. M. Tarasov, R. I. Tymoshenko, O. M. Zahorka. K.: NUOU im. Ivana Chernyakhovs'koho, 2015. 184 p.

3. Zahorka O. M. Do pytannya zastosuvannya rozviduval'no-udarnykh i rozviduval'novohnevykh kompleksiv u merezhetsentrychniy viyni / O. M. Zahorka, V. O. Kolesnykov, V. V. Koval', I. O. Zahorka // Nauka i tekhnika Povitryanykh Syl Zbroynykh Syl Ukrayiny. 2012. № 3. pp. 8-13. Available from: http://nbuv.gov.ua/UJRN/Nitps_2012_3_5.

4. Khomchak R.B., Semnenko O.M., Bokiy V.H., Zvarych A.O., Remez A.V. Teoretychni aspekty prohnozuvannya rezul'tativ rozvytku Zbroynykh Syl Ukrayiny z urakhuvannyam otsinok dostatnosti ekonomichnykh 
mozhlyvostey derzhavy | // Zb. nauk. pr. TSNDI ZS Ukrayiny. Kyyiv. 2020. № 2 (93). pp. 6-24.

5. Razvedyvatel'no-udarnye kompleksy y razvedyvatel'nye systemy ynostrannykh army. Available from: http://studbooks.net/1194609/bzhd/razvedyv atelno_udarnye_kompleksy_razvedyvatelnye_ sistemy_inostranny h_armiy.

6. Boevoe prymenenye raketnykh voysk y artylleryy v operatsyyakh: ucheb. Moscow: VA HSH VS RF, 2006. 304 p.

7. Kosmos y kharakter sovremennykh voennykh deystvyy/ Available from: http://kiksssr.ru/Main_Oko.htm.

8. Semenenko O., Vodchyts O., Bulhakov A., Remez A., Remez V. Methodological approach to justification of decisions on update of samples of weapons and military equipment on the basis of the criteria of economy of economy of performance by them of tasks on purpose // Sciences of Europe, (Praha, Czech Republic), vol 3, № 63 (2021), pp. 49-55

9. Semenenko? O., Remez, A., Musienko, V., Motrunych, I., Bulhakov, A., \& Tarasov, 0. (2021). Recommendations for application of the methodological approach to the military- economic justification of the choice of a rational variant of the reconnaissance-strike system or complex in the programs (plans). Journal of Scientific Papers "Social Development and Security», 11(2), 209-221. DOI: 10.33445/sds.2021.11.2.18

10. Sayapyn O.V., Tykhanychev O.V., Chernov N.A. Sozdanye mezhvydovoy razvedyvatel'noporazhayushchey systemy kak osnovy povyshenyya éffektyvnosty ohnevoho porazhenyya // Voennaya mysl' - 2017. №6. pp. 32-37.

11. Semenenko O.M., Remez A.V., Romanchenko O.A., Bondarenko O.YE. Zahal'na strukturnolohichna skhema ta zmist metodyky voyennoekonomichnoho obgruntuvannya vyboru ratsional'noho variantu rozviduval'no-udarnoyi systemy dlya Zbroynykh Syl Ukrayiny / Zb. nauk. pr. Tsentral'noho naukovo-doslidnoho instytutu Zbroynykh Syl Ukrayiny. Kyiv: TSNDI ZS Ukrayiny, 2020. №4 (95). pp. 36-45.

12. The Implementation of Network-Centric Warfare. Rezhymdostupu: Available from: http://www.iwar.org.uk/ rma /resources/ ncw/ implementation-of-NCW.pdf. 